\title{
Recent Advances in Spectroscopy Technology for Trace Analysis of Persistent Organic Pollutants
}

\author{
Li Wang ${ }^{1}$, Shujie Pang ${ }^{1, *}$ and Gang Zhou ${ }^{2,3, *}$ \\ 1 School of Materials Science and Engineering, Beihang University, Beijing 100083, China \\ 2 School of Biological Science and Medical Engineering, Beihang University, Key Laboratory for Biomechanics \\ and Mechanobiology of Ministry of Education, Beijing 100083, China \\ 3 Shenzhen Research Institute, Beihang University, Shenzhen 518057, China \\ * Correspondence: pangshujie@buaa.edu.cn (S.P.); zhougang@buaa.edu.cn (G.Z.)
}

Received: 23 July 2019; Accepted: 13 August 2019; Published: 21 August 2019

check for updates

\begin{abstract}
Persistent organic pollutants (POPs) have attracted significant attention because of their bioaccumulation, persistence, and toxicity. As anthropogenic products, POPs mainly contain polychlorinated biphenyls (PCBs), organochlorine pesticides (OPs), and polycyclic aromatic hydrocarbons (PAHs), and they pose a great threat to human health and the environment. To deal with these toxic contaminants, many different kinds of strategies for sensitively detecting POPs have been developed, such as high performance liquid chromatography (HPLC), surface enhanced Raman spectroscopy (SERS), and fluorescence. This paper mainly summarized the achievements of spectroscopy technologies, which generally consist of SERS, surface plasmon resonance (SPR), and fluorescence, in the detection of low-concentration POPs in different matrices. In addition, a retrospective summary is made on several critical considerations, such as sensitivity, specificity and reproducibility of these spectroscopy technologies in practical applications. Finally, some current challenges and future outlooks for these spectroscopy technologies are provided in regards to environmental analysis.
\end{abstract}

Keywords: spectroscopy technology; surface enhanced Raman spectroscopy; surface plasmon resonance; fluorescence; persistent organic pollutants

\section{Introduction}

Persistent organic pollutants (POPs) are of global concern due to their toxicity and bioaccumulation in adipose tissue through the food chain [1-4]. They mainly contain polychlorinated biphenyls (PCBs), organochlorine pesticides (OPs), polycyclic aromatic hydrocarbons (PAHs), and some other organic chemicals, such as polychlorinated dibenzo- $p$-dioxins, which are mainly produced by anthropogenic activities [5,6]. POPs can persist for a long time in the environment because of their resistance to degradation, potentially leading to food contamination and threat to human health [7]. As a result, significant attention has been paid to the development of low-cost and reliable methods for the determination of ultratrace concentrations of POPs. Though conventional techniques, such as high-performance liquid chromatography (HPLC) and gas chromatography-mass spectrometry (GC/MS), have great accuracy and widespread applications, most of them suffer from expensive equipment and time-consuming purification processes [8-10]. Therefore, an enormous amount of effort has been devoted to exploring novel strategies like surface-enhanced Raman spectroscopy (SERS) [11,12], enzyme-linked immunosorbent assay (ELISA), and fluorescence [13,14].

Among these emerging methods, spectroscopy technologies are favorable for trace detection of POPs due to their inherent advantages, such as high sensitivity and rapid and real-time monitoring. Spectroscopy technologies generally consist of SERS, surface plasmon resonance (SPR), and fluorescence. 
The reasons for utilizing these methods to detect POPs are as follows: (1) SERS is well suited for detecting POPs due to its capability of providing vibrational spectroscopic fingerprints which indicate the inherent molecular structure of analytes, and allows a limit of detection at very low concentrations, even down to the single molecule level [15-18]; (2) although POPs are small organic molecules, some compounds like PCBs and benzo[a]pyren (i.e., $\mathrm{BaP}$ ) possess a high refractive index. Taking into consideration such properties, the SPR sensor would be much more suitable for trace detection of POPs than any other sensor, such as gravimetric sensors, because it is a refractive-index-sensitive device with label-free detection capability and high sensitivity [19,20]; and (3) the molecular structures of most POPs consist of aromatic rings, which lead them to show inherent fluorescence [21-23]. Thus, fluorescence spectroscopy, as a sensitive analytical method, can be used for the trace detection of POPs.

The investigation of environmental monitoring with spectroscopy technology has motivated some recent review articles that refer to different aspects of primary theory as regards specific applications. This paper was focused on some critical issues and practical applications of spectroscopy technology for the trace detection of POPs. Finally, this paper covered some current challenges and future applied prospects of spectroscopy technology in the detection of small molecular environmental pollutants.

\section{Applications of Spectroscopy Technology in Detection of POPs}

Spectroscopy technology has become more and more attractive for trace detection of POPs in environmental analysis. Though there are reviews detailing the progress of their applications in academic and industrial communities [24-27], a great number of new achievements have been reported in the past few years. These achievements are described as including SERS, SPR sensors, and fluorescence. Some of these achievements and the detection limits are present in Table 1. Figure 1 displays the major applications of spectroscopy technologies in the trace detection of POPs in this work.

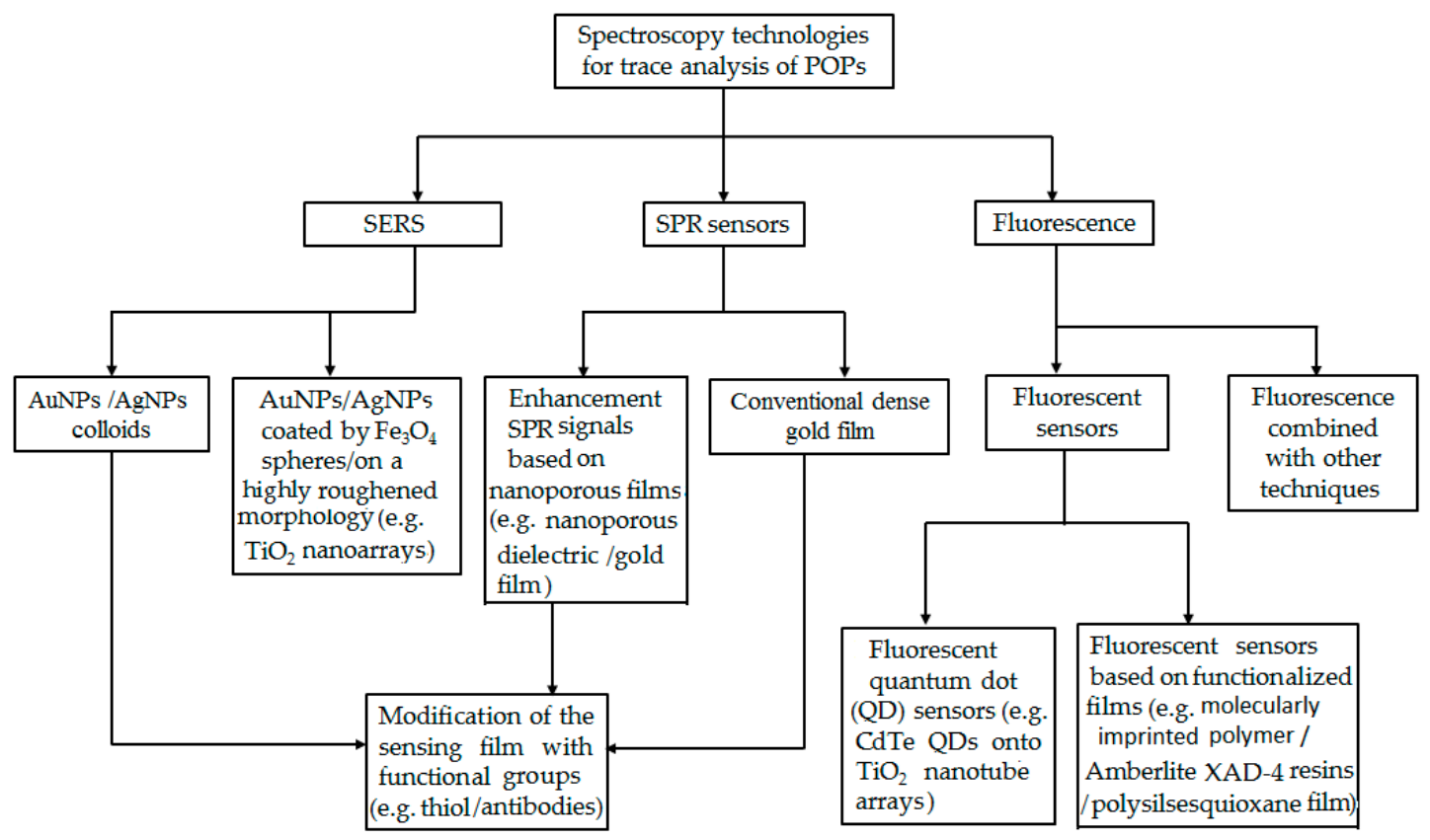

Figure 1. Schematic of the applications of spectroscopy technologies in trace detection of persistent organic pollutants (POPs). 
Table 1. Samples for spectroscopy technologies application in trace detection of POPs.

\begin{tabular}{|c|c|c|c|c|c|c|c|}
\hline \multirow{2}{*}{\multicolumn{2}{|c|}{$\begin{array}{ll} & \text { Spectroscopy Technologies } \\
\text { Analytes } & \end{array}$}} & \multicolumn{2}{|c|}{ SERS } & \multicolumn{2}{|c|}{ SPR } & \multicolumn{2}{|l|}{ Fluorescence } \\
\hline & & Substrate & LOD & Substrate & LOD & Substrate/Method & LOD \\
\hline \multirow{14}{*}{ PAHs } & Pyrene & Au nanoplates & $5 \times 10^{-10} \mathrm{M}[28]$ & 1 & 1 & \multirow{3}{*}{$\begin{array}{l}\text { Fluorescence spectrophotometer based } \\
\text { on a molecularly imprinted polymer } \\
\qquad \text { (MIP) }\end{array}$} & $5 \mathrm{ng} \cdot \mathrm{L}^{-1}[29]$ \\
\hline & Fluoranthene & $\begin{array}{l}\text { Anodic aluminumoxid } \\
\text { based Ag dendritic } \\
\text { substrates }\end{array}$ & $10^{-8} \mathrm{M}[30]$ & / & / & & $5 \eta g \cdot L^{-1}[29]$ \\
\hline & Fluorene & \multirow{11}{*}{$\mathrm{Fe}_{3} \mathrm{O}_{4} @ \mathrm{Au}$ particles } & \multirow[b]{3}{*}{$10^{-7} \mathrm{M}[31]$} & \multirow[b]{3}{*}{ / } & \multirow[b]{3}{*}{ / } & & $6 \eta \mathrm{g} \cdot \mathrm{L}^{-1}[29]$ \\
\hline & Acenaphthylene & & & & & I & I \\
\hline & Acenaphthene & & & & & $\begin{array}{c}\text { Online in-tube solid-phase } \\
\text { microextraction coupled with high- } \\
\text { performance liquid chromatography and } \\
\text { fluorescence detection in hair }\end{array}$ & $5.4 \mathrm{ng} \cdot \mathrm{mL}^{-1}[32]$ \\
\hline & Benzo $[a]$ anthracen & & \multirow{6}{*}{$5 \times 10^{-9} \mathrm{M}[31]$} & \multirow{6}{*}{ / } & \multirow{6}{*}{ / } & $\begin{array}{l}\text { Fluorescence spectrophotometer based } \\
\text { on a molecularly imprinted polymer } \\
\text { (MIP) }\end{array}$ & $7 \mathrm{ng} \cdot \mathrm{L}^{-1}[29]$ \\
\hline & benzo[b]fluoranthene & & & & & $\begin{array}{c}\text { Online in-tube solid-phase } \\
\text { microextraction coupled with high } \\
\text { performance liquid chromatography and } \\
\text { fluorescence detection in hair }\end{array}$ & $2.3 \mathrm{pg} \cdot \mathrm{mL}^{-1}[32]$ \\
\hline & benzo[k]fluoranthene & & & & & UV absorption spectrometry & $0.04 \mu \mathrm{g} \cdot \mathrm{L}^{-1}[33]$ \\
\hline & $\operatorname{Benzo}(g, h i)$ perylene & & & & & \multirow{2}{*}{$\begin{array}{l}\text { Online in-tube solid-phase } \\
\text { microextraction coupled with high- } \\
\text { performance liquid chromatography and } \\
\text { fluorescence detection in hair }\end{array}$} & $\begin{array}{c}5.0 \mathrm{pg} \cdot \mathrm{mL}^{-1} \\
{[32]}\end{array}$ \\
\hline & Indeno(1,2,3-cd)pyrene & & & & & & $\begin{array}{c}20.4 \mathrm{pg} \cdot \mathrm{mL}^{-1} \\
{[32]}\end{array}$ \\
\hline & Chrysene & & & & & $\begin{array}{l}\text { Fluorescence spectrophotometer based } \\
\text { on a molecularly imprinted polymer } \\
\text { (MIP) }\end{array}$ & $5 \eta g \cdot L^{-1}[29]$ \\
\hline & Dibenzo $[a, h]$ anthracene & & $10^{-8} \mathrm{M}[31]$ & / & l & \multirow{2}{*}{$\begin{array}{c}\text { Online in-tube solid-phase } \\
\text { microextraction coupled with high- } \\
\text { performance liquid chromatography and } \\
\text { fluorescence detection in hair }\end{array}$} & $\begin{array}{c}3.3 \mathrm{pg} \cdot \mathrm{mL}^{-1} \\
{[32]}\end{array}$ \\
\hline & Anthracene & & $10^{-8} \mathrm{M}[31]$ & / & I & & $\begin{array}{c}0.5 \mathrm{pg} \cdot \mathrm{mL}^{-1} \\
{[32]}\end{array}$ \\
\hline & Benzo(a)pyrene & $\begin{array}{c}\text { Gold } \\
\text { nanoparticles-embedded } \\
\text { alginate gel }\end{array}$ & $3.65 \times 10^{-10} \mathrm{M}[34]$ & $\begin{array}{l}\text { The nanoporous } \\
\text { gold film }\end{array}$ & $5 \mathrm{pM}[35]$ & $\begin{array}{l}\text { Fluorescence spectrophotometer based } \\
\text { on a molecularly imprinted polymer } \\
\text { (MIP) }\end{array}$ & $3 \eta g \cdot L^{-1}[29]$ \\
\hline
\end{tabular}


Table 1. Cont.

\begin{tabular}{|c|c|c|c|c|c|c|c|}
\hline \multirow{2}{*}{ Analytes } & \multirow{2}{*}{ Spectroscopy Technologies } & \multicolumn{2}{|c|}{ SERS } & \multicolumn{2}{|l|}{ SPR } & \multicolumn{2}{|l|}{ Fluorescence } \\
\hline & & Substrate & LOD & Substrate & LOD & Substrate/Method & LOD \\
\hline & Naphthalene & \multirow{2}{*}{$\begin{array}{l}\text { Hydroxylamine reduced } \\
\text { silver colloid }\end{array}$} & $10^{-12} \mathrm{M}[36]$ & l & l & $\begin{array}{l}\text { Online in-tube solid-phase } \\
\text { microextraction coupled with high- } \\
\text { performance liquid chromatography } \\
\text { and fluorescence detection in hair }\end{array}$ & $\begin{array}{c}9.3 \mathrm{pg} \cdot \mathrm{mL}^{-1} \\
{[32]}\end{array}$ \\
\hline & Phenanthrene & & $10^{-10} \mathrm{M}[36]$ & l & l & $\begin{array}{c}\text { Fluorescence spectrophotometer } \\
\text { based on a molecularly imprinted } \\
\text { polymer (MIP) }\end{array}$ & $6 \eta \mathrm{g} \cdot \mathrm{L}^{-1}[29]$ \\
\hline & Triphenylene & \multirow{3}{*}{$\begin{array}{c}\text { Ag nanoparticles } \\
\text { functionalized with } \\
\text { dithiocarbamate calix } \\
\text { [4] arene }\end{array}$} & $10^{-8} \mathrm{M}[37]$ & 1 & 1 & 1 & 1 \\
\hline & Benzo[c]phenanthrene & & $10^{-9} \mathrm{M}[37]$ & 1 & 1 & 1 & 1 \\
\hline & Coronene & & $10^{-10} \mathrm{M}[37]$ & 1 & 1 & 1 & 1 \\
\hline \multirow{9}{*}{ PCBs } & $\begin{array}{l}\text { 3,3' }, 5,5^{\prime} \text {-tetrachlorobiphenyl } \\
\text { (PCB 80) }\end{array}$ & l & l & $\begin{array}{l}\text { Gold thin film } \\
\text { immobilized with } \\
\text { Cytochrome c }\end{array}$ & $0.1 \mathrm{ppb}[38]$ & l & l \\
\hline & $\begin{array}{l}\text { 2,3,3',4,4'-tetrachlorobiphenyl } \\
\text { (PCB105) }\end{array}$ & l & l & l & l & $\begin{array}{l}\text { Photoactivated fluorescence } \\
\text { procedure with a laser system for } \\
\text { photoactivation }\end{array}$ & $\begin{array}{c}0.05 \mu \mathrm{g} \cdot \mathrm{mL}^{-1} \\
{[39]}\end{array}$ \\
\hline & 4-chlorobiphenyl (PCB3) & l & l & l & l & \multirow{7}{*}{$\begin{array}{l}\text { Extraction/concentration with tab- } \\
\text { shaped elements cut from C18 fiber } \\
\text { glass SPE disks coupled with a } \\
\text { fluorescence detection }\end{array}$} & $\begin{array}{c}0.07 \mu \mathrm{g} \cdot \mathrm{L}^{-1} \\
{[40]}\end{array}$ \\
\hline & $\begin{array}{l}\text { 4, } 4^{\prime} \text {-dichlorobiphenyl } \\
\text { (PCB15) }\end{array}$ & l & l & l & / & & $\begin{array}{c}0.40 \mu \mathrm{g} \cdot \mathrm{L}^{-1} \\
{[40]}\end{array}$ \\
\hline & $\begin{array}{l}\text { 3,4, } 4^{\prime} \text {-trichlorobiphenyl } \\
\text { (PCB37) }\end{array}$ & I & 1 & I & l & & $\begin{array}{c}0.30 \mu \mathrm{g} \cdot \mathrm{L}^{-1} \\
{[40]}\end{array}$ \\
\hline & $\begin{array}{l}2,3^{\prime}, 4,4^{\prime}-5-\text { Pentachlorobiphenyl } \\
\text { (PCB118) }\end{array}$ & I & I & l & I & & $\begin{array}{c}\text { 1. } 0 \mu \mathrm{g} \cdot \mathrm{L}^{-1} \\
{[40]}\end{array}$ \\
\hline & $\begin{array}{c}3,3^{\prime}, 4,4^{\prime} \\
\text { 5-pentachlorobiphenyl } \\
\text { (PCB126) }\end{array}$ & I & l & l & l & & $\begin{array}{l}0.80 \mu \mathrm{g} \cdot \mathrm{L}^{-1} \\
{[40]}\end{array}$ \\
\hline & $\begin{array}{c}3,3^{\prime}, 4,4^{\prime}, \\
5,5^{\prime} \text {-Hexachlorobiphenyl } \\
\text { (PCB169) }\end{array}$ & l & l & l & l & & $\begin{array}{l}0.20 \mu \mathrm{g} \cdot \mathrm{L}^{-1} \\
{[40]}\end{array}$ \\
\hline & $\begin{array}{c}\text { 2,2',3,4,5'-pentachlorobiphenyl } \\
\text { (PCB87) }\end{array}$ & I & 1 & I & I & & $\begin{array}{c}1.0 \mu \mathrm{g} \cdot \mathrm{L}^{-1} \\
{[40]}\end{array}$ \\
\hline
\end{tabular}


Table 1. Cont.

\begin{tabular}{|c|c|c|c|c|c|c|c|}
\hline \multirow{2}{*}{ Analytes } & \multirow{2}{*}{ Spectroscopy Technologies } & \multicolumn{2}{|c|}{ SERS } & \multicolumn{2}{|l|}{ SPR } & \multicolumn{2}{|l|}{ Fluorescence } \\
\hline & & Substrate & LOD & Substrate & LOD & Substrate/Method & LOD \\
\hline & $\begin{array}{c}2,3,3^{\prime}, 4^{\prime}, 6^{\prime} \text {-pentachlorobiphenyl } \\
\text { (PCB110) }\end{array}$ & l & l & l & l & & $\begin{array}{l}6.0 \mu \mathrm{g} \cdot \mathrm{L}^{-1} \\
\quad[40]\end{array}$ \\
\hline & $\begin{array}{l}3,3^{\prime}, 4,4^{\prime} \text {-tetrachlorobiphenyl } \\
\text { (PCB77) }\end{array}$ & $\begin{array}{l}\text { Ag-NPassembled } \\
\text { Bi-nanoring Arrays }\end{array}$ & $10^{-9} \mathrm{M}[41]$ & l & l & & $\begin{array}{l}0.50 \mu \mathrm{g} \cdot \mathrm{L}^{-1} \\
{[40]}\end{array}$ \\
\hline & $\begin{array}{l}2,2^{\prime}, 3,3^{\prime} \text {-tetrachlorobiphenyl } \\
\text { (PCB40) }\end{array}$ & \multirow{3}{*}{$\begin{array}{l}\text { Nanostructured GO } \\
\text { assemblies with Ag } \\
\text { nanoprisms }\end{array}$} & $10^{-7} \mathrm{M}[42]$ & l & l & l & l \\
\hline & $\begin{array}{l}\text { 2,2',5,5'-tetrachlorobiphenyl } \\
\text { (PCB52) }\end{array}$ & & $3.33 \times 10^{-4} \mathrm{M}[42]$ & l & / & l & / \\
\hline & $\begin{array}{l}\text { 2,2',4,4'-tetrachlorobiphenyl } \\
\text { (PCB47) }\end{array}$ & & $5 \times 10^{-11} \mathrm{M}[43]$ & l & / & l & / \\
\hline & 3-chlorobiphenyl (PCB2) & \multirow{2}{*}{$\begin{array}{c}\beta \text {-cyclodextrin coated } \\
\mathrm{SiO}_{2} @ \text { Au@Ag core/shell } \\
\text { nanoparticles }\end{array}$} & \multirow{2}{*}{$10^{-6} \mathrm{M}[44]$} & 1 & 1 & 1 & 1 \\
\hline & 2,4,5-trichlorobiphenyl (PCB29) & & & 1 & 1 & 1 & 1 \\
\hline \multirow{6}{*}{ OPs } & Chlorpyrifos & $\begin{array}{l}\text { Colloidal gold } \\
\text { nanoparticles }\end{array}$ & $\begin{array}{c}3.51 \mathrm{ng} \cdot\left(\mathrm{cm}^{2}\right)^{-1} \\
{[45]}\end{array}$ & $\begin{array}{l}\text { SPR chip coated by } \\
\text { magnetic molecular } \\
\text { imprinting polymer } \\
\text { chlorpyrifos }\end{array}$ & $\begin{array}{c}0.76 \mathrm{nM} \\
{[46]}\end{array}$ & CdTe QD Fluorescence Switch & $0.1 \mathrm{nM}[47]$ \\
\hline & endosulfan & \multirow{4}{*}{$\begin{array}{l}\text { Silver and gold colloids } \\
\text { functionalized with } \\
\text { alkyl dithiols }\end{array}$} & $170 \mu \mathrm{g} \cdot \mathrm{L}^{-1}[48]$ & l & / & $\begin{array}{l}\text { Time-resolved fluorescence in } \\
\text { microtiter plates }\end{array}$ & $0.004 \mu \mathrm{M}[49]$ \\
\hline & Lindane & & $1028 \mu \mathrm{g} \cdot \mathrm{L}^{-1}[48]$ & I & 1 & l & 1 \\
\hline & dieldrin & & $316 \mu \mathrm{g} \cdot \mathrm{L}^{-1}[48]$ & I & 1 & I & 1 \\
\hline & aldrin & & $45 \mu \mathrm{g} \cdot \mathrm{L}^{-1}[48]$ & 1 & 1 & l & 1 \\
\hline & DDT & l & l & $\begin{array}{l}\text { Dense gold film } \\
\text { functionalized by } \\
\text { alkanethiol } \\
\text { monolayer }\end{array}$ & $\begin{array}{l}15 \mathrm{ng} \cdot \mathrm{L}^{-1} \\
{[50]}\end{array}$ & l & l \\
\hline
\end{tabular}

The concentration unit moles per liter $\left(\mathrm{mol} \cdot \mathrm{L}^{-1}\right)$ was abbreviated as " $\mathrm{M}^{\text {". }}$ 


\subsection{SERS}

SERS is based on the enhancement of the Raman scattering signals of targeted molecules, which are able to interact with nanostructured metallic surfaces under the right conditions [51]. The SERS phenomenon was originally reported in the 1970s by Fleischman and coworkers [52]. They first noticed the enhanced performance of Raman scattering from a pyridine monolayer adsorbed on an electrochemically roughened silver electrode. However, the first report introducing of the SERS technique for the detection of PAHs was in 1990s by Kronfeldt et al. [53]. They fabricated silver SERS-active substrates using sol-gel methods, and investigated PAHs in artificial seawater with a detection limit up to nanomolar concentrations. Subsequently, two different strategies were used in the improvement of substrates to further enhance the sensitivity of SERS detection. One of them is the construction of substrates with specific geometries, which possess abundant nanogaps ("hot spots") and contribute to effectively enriching targeted molecules by physical adsorption [54,55], and the other is modification of the substrate surface with functional molecules like antibodies and aptamers to facilitate targeted molecules with low affinity to approach localized electromagnetic fields [56].

Sensitivity of SERS detection mainly depends on the nanostructures of the substrates [57]. In other words, these metallic plasmonic nanostructures, referred to as SERS-active substrates, are of importance for observing the SERS phenomenon, as well as the detection sensitivity. The high sensitivity of SERS detection can be achieved by preparing elaborate substrates with large amounts of hot spots and huge surface areas [58]. For example, highly sensitive SERS substrates can be constructed by $\mathrm{Fe}_{3} \mathrm{O}_{4}$ microspheres and AuNPs $\left(\mathrm{Fe}_{3} \mathrm{O}_{4} @\right.$ Au nanoparticles), for which $\mathrm{Fe}_{3} \mathrm{O}_{4}$ microparticles could render an inhomogeneous distribution of local plasmon resonance and lead to a local increase in the electromagnetic field density. A significant SERS enhancement of the substrate was attributed to the interparticle gap between AuNPs grafted on $\mathrm{Fe}_{3} \mathrm{O}_{4}$ (Figure 2A) [31] and the detection limits of PAHs, such as benzo [a] anthracen and benzo $(g, h i)$ perylene, and were up to $5 \mathrm{nmol} \cdot \mathrm{L}^{-1}$ (Table 1$)$. In addition, AuNPs and silver nanoparticles (AgNPs) can be coated on a highly roughened morphology instead of a smooth surface to fabricate an ultrasensitive substrate [59,60]. Figure 2B shows AgNPs sputtered in bi-nanorings to acquire optimal substrates, which exhibited excellent analytical performance for PCBs with a detection limit of $1 \mathrm{nmol} \cdot \mathrm{L}^{-1}$ [41]. In addition to these, nanosensors fabricated with an aggregation of AgNPs and AuNPs functionalized by dithiols could be used to identify and quantify OPs (including aldrin, $\alpha$-endosulfan, dieldrin and lindane) (Figure 2C), with the lowest detection limit of aldrin being down to $45 \mu \mathrm{g} \cdot \mathrm{L}^{-1}$ [48]. Figure 2D shows the SERS spectra of analyzed OPs. Limits of detection for analyzed OPs were different, and probably resulted from their showing different affinities to the metal surfaces of the substrates. The maximum detection efficiency was obtained for substrates possessing a maximum number of binding sites just at the formed hot spots localized in the gaps between nanoparticles. These achievements have significantly improved the sensitivity of SERS detection for POPs, and SERS has become a powerful spectroscopic technique for analyzing low-concentration contaminants; however, continuous efforts will be devoted to extending novel fabrication of SERS substrates in the future.

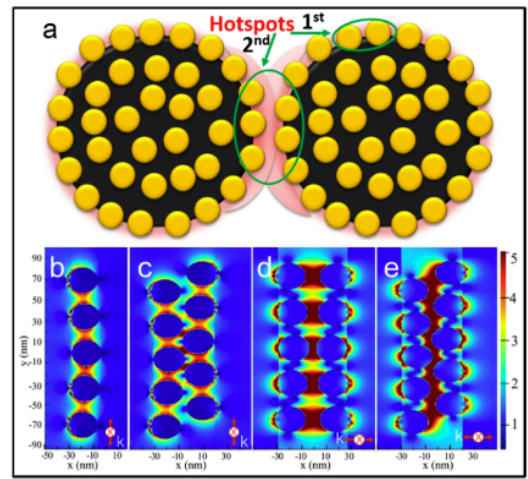

(A)

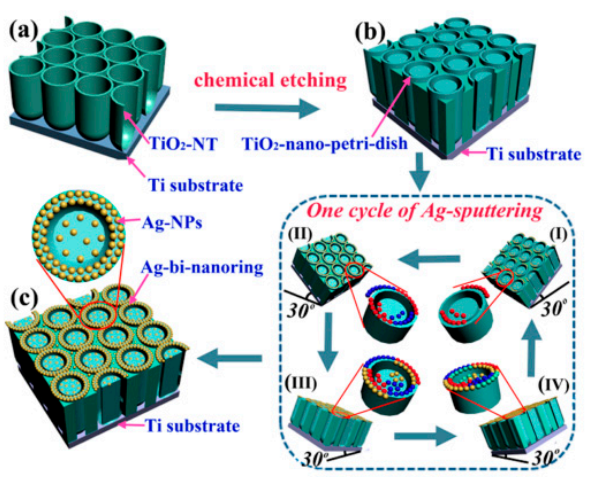

(B)

Figure 2. Cont. 




(C)

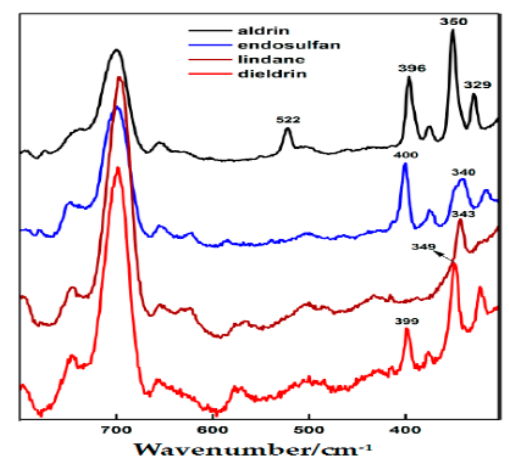

(D)

Figure 2. (A) Schematic of the plasmonic hot spots formed on $\mathrm{Fe}_{3} \mathrm{O}_{4} @ \mathrm{Au} \mathrm{NPs}$ (nanoparticles) (a), calculated electric field intensity distribution induced by localized surface plasmon resonance (LSPR) on the $\mathrm{Fe}_{3} \mathrm{O}_{4} @ \mathrm{Au}$ system (b-e). (B) Diagram of the construction of AgNPs assembled bi-nanoring arrays $(\mathrm{a}-\mathrm{c})$. Lower-right panel is a schematic for one cycle of glancing angle sputtering. (C) Illustration of the pesticide hosting in the dithiol layer organized in interparticle gaps between metal NPs. (D) Surface enhanced Raman spectroscopy (SERS) spectra of aldrin, endosulfan, lindane, and dieldrin on DT8(1,8-octanedithiol)-functionalized citrate AgNPs exciting at $785 \mathrm{~nm}$. Republished with permission from [31,41,48] (Copyright (C) 2016, Elsevier; Copyright (C) 2014, American Chemical Society).

\subsection{SPR Sensors}

SPR is wave sensing technique that can detect biochemical reactions in the near-field region [61-63]. The SPR phenomenon was first discovered in 1900s by Wood. As he measured the reflection of metallic gratings, he found that some optical power of polarized incident light was absorbed by metal because of the excitation of surface plasma waves (SPW) [64]. Subsequently, the investigation of SPR sensing was motivated after the introduction of attenuated total internal reflection (ATR) by Otto and Kretschmann in 1968 [65,66]. However, the original investigation, bringing SPR technique into the biochemical sensing field and detailing the application of the SPR sensor, was published in the 1980s by Nylander and Liedberg [67]. They first employed the SPR technique for gas detection and demonstrated that the method was able to monitor low-concentrations of anesthetic gas, which made the pioneering work practical for applications of the SPR sensor in the biochemical field. Since then SPR sensors have become a valuable platform for low-level detection of environmental pollutants [68].

SPR sensors are one of the favorable strategies in determination of POPs, due to their many advantages, such as high sensitivity and selectivity, label-free detection, rapid response [69-71]. Conventional SPR sensors with dense sensing films cannot directly detect small molecules, due to the extremely small depth between the evanescent field and surface-bound molecules. Thus, abundant biorecognition elements can be immobilized on the surface of the sensing film to fabricate SPR biosensors that show a high specificity for targeted molecules. Some typical strategies for functionalization of sensing surfaces are illustrated in Figure 3 [72]. Any of these methods could greatly improve the amounts of target molecules anchored on the sensing surface and amplify the SPR signal. Miura et al. investigated the detection of BaP by SPR immunosensors with the indirect inhibition method in 2002 [73]. They immobilized BaP conjugated with bovine serum albumin (BSA) on a dense gold surface of a sensing film as $\mathrm{BaP}$ has a low-molecular weight. The experimental results indicated that the incident angle changed as the samples of antibodies against $\mathrm{BaP}$ at different concentrations were injected into, and flowed through, the sensor chip. The detection limit of this method was up to $0.1 \mathrm{ppb}$. A similar strategy was employed by Hong et al. who detected PCB using the SPR technique in 2008 [38]. The detection mechanism was based on PCB-induced conformational changes of Cytochrome c (Cyt c) immobilized on the dense gold film, altering the local dielectric function of the supported Cyt c, which can be detected by SPR (Figure 4a). The confirmations of Cyt c sensitively varied with the changes of PCB concentrations, and the reflectance $R$ at the SPR angle of the supported 
Cyt c increased with increasing PCB concentrations. The detection limit was as low as $0.1 \mathrm{ppb}$ and the responses could be finished in less than $10 \mathrm{~min}$.

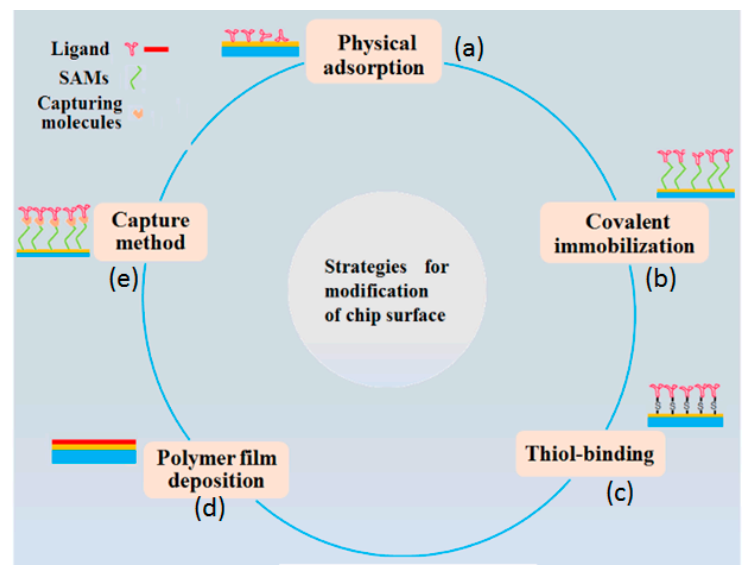

Figure 3. Common strategies for preparation of modified surface including: (a) Physical adsorption, (b) covalent immobilization (thiol-based and self-assembled monolayers (SAMs)-based), (c) capture and (d) polymer film deposition methods.
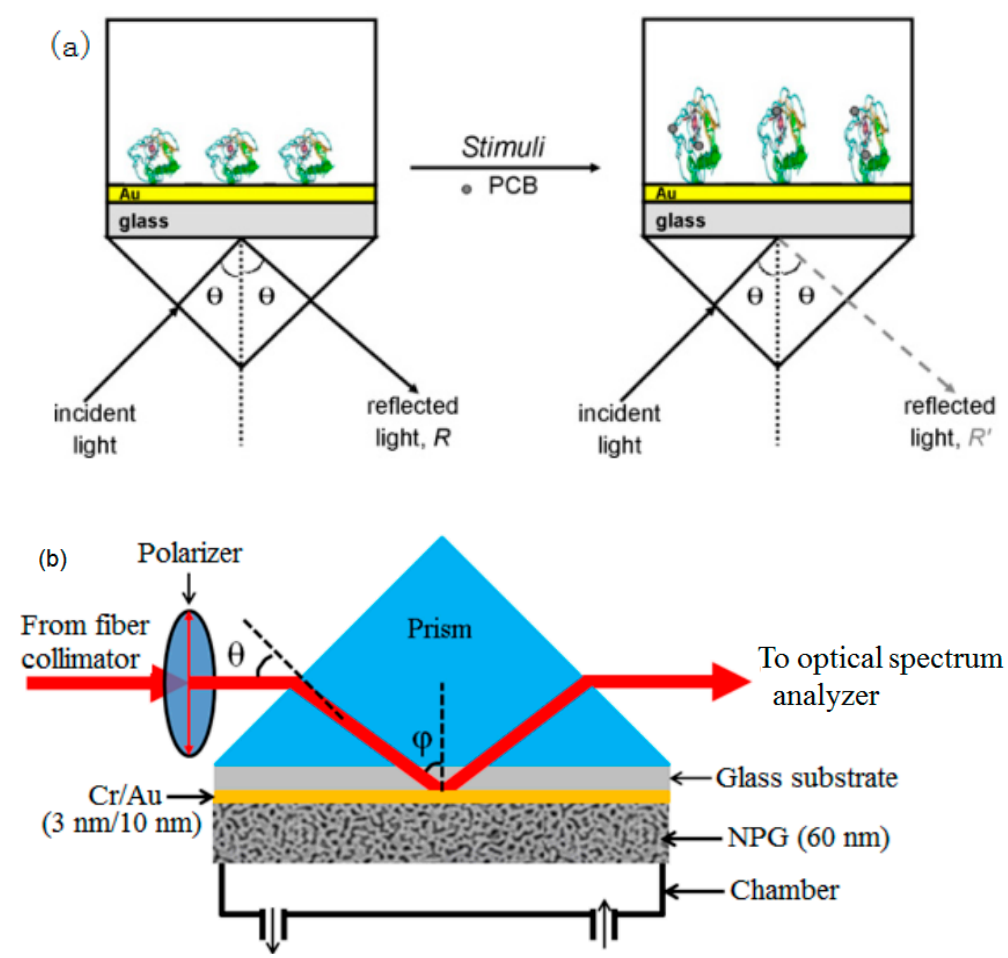

Figure 4. (a) Schematic of polychlorinated biphenyl (PCB)-sensitive optical detection system using surface plasmon resonance, (b) Illustration of surface plasmon resonance (SPR) sensors based on the nanoporous gold (NPG) film. Republished with permission from [35,38] (Copyright (C) 2008, Elsevier).

The porous dielectric film immobilized on the SPR sensor chip is an effective method to dramatically improve the sensitivity, due to it possessing a large internal surface area and extending the interaction depth to the entire thickness of the film [74,75]. However, this makes the fabrication process of the SPR sensors complicated and exhaustive. To overcome this problem, Wang et al. adopted nanoporous gold (NPG) film as an effective and alternative approach for the SPR sensor in the trace detection of BaP [35]. The NPG film could not only dramatically enhance the sensitivity for the great enrichment of BaP throughout the entire thickness but also support the surface plasmon wave with a simple structure of the SPR sensor (Figure $4 \mathrm{~b}$ ). The detection limit for $\mathrm{BaP}$ was $5 \mathrm{pmol} \cdot \mathrm{L}^{-1}$, which was increased by 20 times 
compared to that of conventional SPR sensors (Figure 5). Therefore, this suggested that the technique in SPR sensors shows enormous potential for trace detection and monitoring of small-molecular environmental pollutants [35].
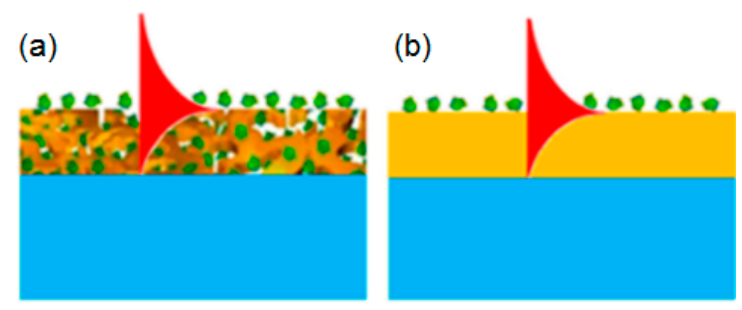

Figure 5. Schematic diagram illustration of the difference in evanescent wave interaction with adsorbed molecules between (a) the nanoporous gold film and (b) dense gold film [35].

\subsection{Fluorescence}

Fluorescence is an amazing natural phenomenon which can be observed at a longer wavelength after the excitation of fluorescent materials at a shorter wavelength. Its original explanation was provided by Sir George Gabriel Stokes around 1850 [76]. The investigations of fluorescence-based biological strategies began to develop in the 1950s, due to the availability of commercial fluorescence instrumentation [77]. So far, fluorescence spectroscopic techniques have been widely recognized as useful tools in analytical chemistry, especially due to their high inherent sensitivity [78]. Hence, fluorescence-based techniques like fluorescence sensors using nanomaterials have been suggested as a possible alternative to conventional methods [79-81].

Sensitivity of fluorescent sensors strongly depends on the nanostructure and morphology of the sensing film. Such sensors can be used to determine trace POPs by functionalizing the chip surface with functional groups to effectively preconcentrate targeted molecules [82,83]. For example, optosensors based on the online immobilization of BaP using Amberlite XAD-4 could detect BaP in a continuous-flow system with the limit of detection up to $3 \mathrm{ng} \cdot \mathrm{L}^{-1}$ [84]. Among PAHs, only $\mathrm{BaP}$ can interact with Amberlite XAD-4 resins and shows strong fluorescence at the excitation wavelength $\lambda=392 \mathrm{~nm}$. Additionally, fluorescent quantum dot (QD) sensors based on the mechanism of fluorescence resonance energy transfer (FRET) have been extensively studied and applied to detect POPs, due to their high selectivity and sensitivity and a wider applicability [85]. As optical sensors constructed by coating $\mathrm{CdTe}$ QDs onto $\mathrm{TiO}_{2}$ nanotube (NT) arrays which possess a huge surface area (Figure 6A), the fluorescence intensity of BaP was amplified 15 times compared to that of the direct liquid fluorescent spectrometry [86]. The sensitivity obtained using this method to PAHs depended on the number of their fused aromatic rings, with the highest sensitivity to $\mathrm{BaP}$ and the detection limit down to $15 \mathrm{pmol} \cdot \mathrm{L}^{-1}$. The fluorescence enhancement was contributed to the fluorescence energy transfer from CdTe QDs to BaP. Beyond these, fluorescent sensors functionalized with polysilsesquioxane film can be used to detect PCBs, based on the mechanism that their fluorescence emission intensity decreased steadily with a corresponding increase in PCBs, which was shown in Figure 6B [82]. The detection limit of PCB77 came up to $8.03 \times 10^{-7} \mathrm{~mol} \cdot \mathrm{L}^{-1}$. So far, fluorescence, including its combination with other techniques, has been used to detect different kinds of POPs and has seen notable achievements, detailed in Table 1. This can bring about a new research trend in environmental analysis. 




(A)

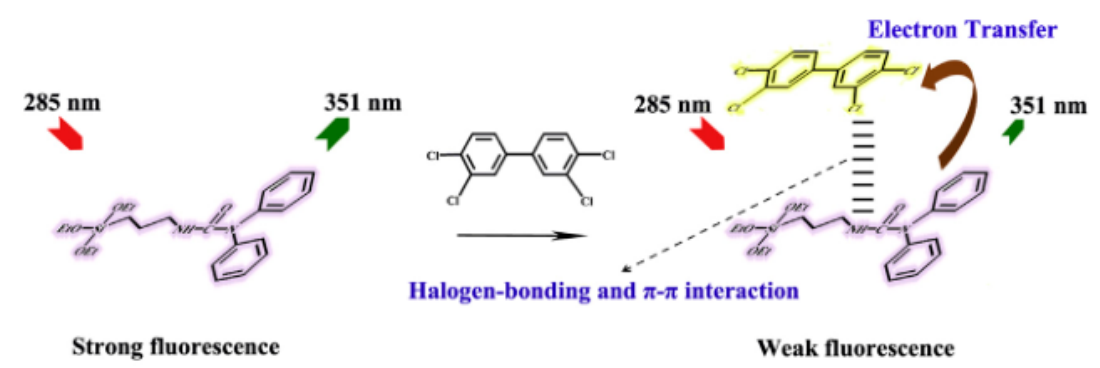

(B)

Figure 6. (A) SEM images of the lateral view and top view (inset) of $\mathrm{TiO}_{2} \mathrm{NTs}$ (a) and $\mathrm{CdTe}-\mathrm{TiO}_{2}$ NTs (b). (B) Schematic representation of photo-induced electron transfer mechanism for fluorescence quenching of g-(N,N-diphenylcarbamino)propyltriethoxysilane (DPTES) by PCB77. Republished with permission from [82,86] (Copyright (C) 2014, Elsevier; Copyright (C) 2010, American Chemical Society).

\subsection{Some Considerations in Spectroscopy Technology Detection of POPS}

Conventional environmental analysis generally requires accurate determination and quantification of low-concentration chemical pollutants in complex surroundings. As a result, the development of spectroscopy technology should consider some specific detection properties, such as sensitivity, selectivity, and reproducibility. The above-mentioned spectroscopy technologies possess the potential to meet these requirements because of their unique features.

Though each of these spectroscopy technologies have some defects and drawbacks, there are some notable achievements that have already put forward a series of effective strategies to address these problems. Some of the methodologies were as follows: (1) Novel nanostructures, which could offer large surface areas and great amounts of functionalized binding sites for targeted molecules, which could greatly enhance detection sensitivity. In addition, surface hydrophobicity of the substrates by chemical and physical methods can also effectively enrich the targeted molecules; (2) exquisite specificity and high affinity of antibody-antigen interactions lead to dramatic sensitivity enhancement and can reduce the detection limit of POPs to sub-nanomolar levels; (3) excellent reproducibility, which can validate the reliability and repeatability of the experimental results, benefits from well-ordered and uniform nanostructure and morphology of the substrates of optical sensors. Finally, the miniaturization of the optical instruments and the development of spectroscopy technology facilitates portability for field detection.

\section{Conclusions and Prospects}

In this work, recent advances in spectroscopy technologies, such as SERS, SPR, and fluorescence for trace detection of POPs were summarized. It has been demonstrated that high sensitivity and selectivity can be obtained by designing elaborate nanostructures for the substrates and improving specificity and affinity for targeted molecules. The investigations of these achievements could support some novel strategies for monitoring various environmental pollutants in the future.

Nowadays spectroscopy technology is confronted by some challenges in the practical implementation of low-level detection of POPs with complex samples. Though great efforts have been 
made to enhance sensitivity and reproducibility, some problems still exist in the reliable analysis of ultratrace concentration and eliminating the interference of other coexisting pollutants. Thus, great attention still should be given to these problems to achieve a higher sensitivity and more accurate monitoring of POPs in complex matrices. Furthermore, the coupling of spectroscopy technologies with other methods will be much better for separation of coexisting pollutants and providing comprehensive and accurate information of targeted molecules during the whole experiment. We anticipate that it will be a popular trend in the future. Continued investigations in this field will significantly improve the practical applications of spectroscopy technologies in the trace analysis of various environmental pollutants.

Author Contributions: L.W. conceived and wrote this manuscript; S.P. and G.Z. provided guidance and suggestions for this manuscript. All authors read and approved the manuscript.

Funding: This research was financially supported by the National Key Research and Development Program (2016YFC1100704, 2016YFC1102203, 2017YFC0108505), the Fundamental Research Funds for the Central Universities (No. YWF-19-BJ-J-203), NSFC Research Grant (11827803, 11421202, 61227902, 31470901), National Key Technology R\&D Program (No. 2014BAI11B15), Beijing Municipal Science and Technology Project (No. Z141107002514073), Beijing Municipal Administration of Hospitals Clinical Medicine Development of Special Funding (No. ZYLX201508), the capital health research and development of special funding (No. 2014-1-2091), the 111 Project of China (No. B13003) and Science, Technology and Innovation Commission of Shenzhen Municipality.

Acknowledgments: Thanks Michael Anderson (Department of Neuroscience, School of Medicine, Johns Hopkins University) for English editing.

Conflicts of Interest: We declare that we have no conflicts of interest to this work.

\section{References}

1. Kumar, J.; Lind, P.M.; Salihovic, S.; Bavel, B.; Ekdahl, K.N.; Nilsson, B.; Lind, L.; Ingelsson, E. Influence of persistent organic pollutants on the complement system in a population-based human sample. Environ. Int. 2014, 71, 94-100. [CrossRef] [PubMed]

2. Pariatamby, A.; Kee, Y.L. Persistent Organic Pollutants Management and Remediation. Procedia Environ. Sci. 2016, 31, 842-848. [CrossRef]

3. Augusto, S.; Máguas, C.; Branquinho, C. Guidelines for biomonitoring persistent organic pollutants (POPs), using lichens and aquatic mosses-A review. Environ. Pollut. 2013, 180, 330-338. [CrossRef] [PubMed]

4. Bajaj, S.; Singh, D.K. Biodegradation of persistent organic pollutants in soil, water and pristine sites by cold-adapted microorganisms: Mini review. Int. Biodeterior. Biodegrad. 2015, 100, 98-105. [CrossRef]

5. Wang, X.; Hao, W.; Zhang, H.; Pan, Y.; Kang, Y.; Zhang, X.; Zou, M.; Tong, P.; Du, Y. Analysis of polycyclic aromatic hydrocarbons in water with gold nanoparticles decorated hydrophobic porous polymer as surface-enhanced Raman spectroscopy substrate. Spectrochim. Acta Part A Mol. Biomol. Spectrosc. 2015, 139, 214-221. [CrossRef] [PubMed]

6. Starek-Świechowicz, B.; Budziszewska, B.; Starek, A. Hexachlorobenzene as a persistent organic pollutant: Toxicity and molecular mechanism of action. Pharmacol. Rep. 2017, 69, 1232.

7. Johnson, P.I.; Stapleton, H.M.; Sjodin, A.; Mekeer, J.D. Relationships between Polybrominated Diphenyl Ether Concentrations in House Dust and Serum. Environ. Sci. Technol. 2010, 44, 5627-5632. [CrossRef]

8. Kato, K.; Shoda, S.; Takahashi, M.; Doi, N.; Yoshimura, Y.; Nakazawa, H. Determination of three phthalate metabolites in human urine using on-line solid-phase extraction-liquid chromatography-tandem mass spectrometry. J. Chromatogr. B 2003, 788, 407-411. [CrossRef]

9. Olatunji, O.S.; Fatoki, O.S.; Opeolu, B.O.; Ximba, B.J. Determination of polycyclic aromatic hydrocarbons [PAHs] in processed meat products using gas chromatography-Flame ionization detector. Food Chem. 2014, 156, 296-300. [CrossRef]

10. Ratola, N.; Lacorte, S.; Barceló, D.; Alves, A. Microwave-assisted extraction and ultrasonic extraction to determine polycyclic aromatic hydrocarbons in needles and bark of Pinus pinaster Ait. And Pinus pinea L. by GC-MS. Talanta 2009, 77, 1120-1128. [CrossRef]

11. Du, J.; Jing, C. Preparation of Thiol Modified $\mathrm{Fe}_{3} \mathrm{O}_{4} @ \mathrm{Ag}$ Magnetic SERS Probe for PAHs Detection and Identification. J. Phys. Chem. C 2011, 115, 17829-17835. [CrossRef] 
12. López-Tocón, N.I.; Otero, J.C.; Arenas, J.F.; Garcia-Ramos, J.V.; Sanchez-Cortes, S. Multicomponent Direct Detection of Polycyclic Aromatic Hydrocarbons by Surface-Enhanced Raman Spectroscopy Using Silver Nanoparticles Functionalized with the Viologen Host Lucigenin. Anal. Chem. 2011, 83, 2518-2525. [CrossRef]

13. Karsunke, X.Y.; Pschenitza, M.; Rieger, M.; Weber, E.; Niessner, R.; Knopp, D. Screening and characterization of new monoclonal anti-benzo[a]pyrene antibodies using automated flow-through microarray technology. J. Immunol. Methods 2011, 371, 81-90. [CrossRef]

14. Hua, G.; Killham, K.; Singleton, I. Potential application of synchronous fluorescence spectroscopy to determine benzo[a]pyrene in soil extracts. Environ. Pollut. 2006, 139, 272-278. [CrossRef] [PubMed]

15. Smith, W.E. Practical understanding and use of surface enhanced Raman scattering/surface enhanced resonance Raman scattering in chemical and biological analysis. Chem. Soc. Rev. 2008, 37, 955-964. [CrossRef]

16. Pieczonka, N.P.W.; Aroca, R.F. ChemInform Abstract: Single Molecule Analysis by Surfaced-Enhanced Raman Scattering. Cheminform 2010, 39, 946. [CrossRef]

17. Sarfo, D.K.; Izake, E.L.; O'Mullane, A.P.; Ayoko, G.A.A. Molecular recognition and detection of $\mathrm{Pb}$ (II) ions in water by aminobenzo-18-crown-6 immobilised onto a nanostructured SERS substrate. Sens. Actuators B 2018, 255, 1945-1952. [CrossRef]

18. Yang, L.; Chen, Y.; Shen, Y.; Yang, M.; Li, X.; Han, X.; Jiang, X.; Zhao, B. SERS strategy based on the modified Au nanoparticles for highly sensitive detection of bisphenol A residues in milk. Talanta 2018, $179,37$. [CrossRef] [PubMed]

19. Rifat, A.A.; Mahdiraji, G.A.; Sua, Y.M.; Ahmed, R.; Shee, Y.G.; Adikan, F.R. Highly sensitive multi-core flat fiber surface plasmon resonance refractive index sensor. Optics Express 2016, 24, 2485. [CrossRef]

20. Giorgini, A.; Avino, S.; Malara, P.; Gagliardi, G.; Casalino, M.; Coppola, G.; Iodice, M.; Adam, P.; Chadt, K.; Homola, J.; et al. Surface plasmon resonance optical cavity enhanced refractive index sensing. Opt. Lett. 2013, 38, 1951-1953. [CrossRef] [PubMed]

21. Das, D.; Sahoo, G.P.; Mazumdar, P.; Maity, A.; Chattopadhyay, D.; Guillermo, S.M. Morphology directing synthesis of benzo[a]pyrene microstructures and their photo physical properties. J. Mol. Liquids 2015, 206, 47-55. [CrossRef]

22. Costa, J.C.S.; Sant'Ana, A.C.; Corio, P.; Temperini, M.L. Chemical analysis of polycyclic aromatic hydrocarbons by surface-enhanced Raman spectroscopy. Talanta 2006, 70, 1011-1016. [CrossRef] [PubMed]

23. Nahorniak, M.L.; Booksh, K.S. Excitation-emission matrix fluorescence spectroscopy in conjunction with multiway analysis for PAH detection in complex matrices. Analyst 2006, 131, 1308-1315. [CrossRef] [PubMed]

24. Li, D.W.; Zhai, W.L.; Li, Y.T.; Long, Y.T. Recent progress in surface enhanced Raman spectroscopy for the detection of environmental pollutants. Microchim. Acta 2014, 181, 23-43. [CrossRef]

25. Singh, P. SPR Biosensors: Historical Perspectives and Current Challenges. Sens. Actuators B Chem. 2016, 229, 110-130. [CrossRef]

26. Ho, A.H.-P.; Kim, D.; Somekh, M.G. Handbook of Photonics for Biomedical Engineering; Springer: Dordrecht, The Netherlands, 2017; pp. 1-19.

27. Morris May, C. Fluorescence-Based Biosensors; Elsevier/Academic Press: Cambridge, MA, USA, 2013; pp. 193-216.

28. Lin, W.H.; Lu, Y.H.; Hsu, Y.J. Au nanoplates as robust, recyclable SERS substrates for ultrasensitive chemical sensing. J. Colloid Interface Sci. 2014, 418, 87-94. [CrossRef] [PubMed]

29. Krupadam, R.J.; Bhagat, B.; Wate, S.R.; Bodhe, G.L.; Sellergren, B.; Anjaneyulu, A. Fluorescence Spectrophotometer Analysis of Polycyclic Aromatic Hydrocarbons in Environmental Samples Based on Solid Phase Extraction Using Molecularly Imprinted Polymer. Environ. Sci. Technol. 2009, 43, 2871-2877. [CrossRef] [PubMed]

30. Zhang, C.Y.; Lu, Y.; Zhao, B.; Hao, Y.W.; Liu, Y.Q. Facile fabrication of Ag dendrite-integrated anodic aluminum oxide membrane as effective three-dimensional SERS substrate. Appl. Surface Sci. 2016, 377, 167-173. [CrossRef]

31. Du, J.; Xu, J.; Sun, Z.; Jing, C. Au nanoparticles grafted on $\mathrm{Fe}_{3} \mathrm{O}_{4}$ as effective SERS substrates for label-free detection of the 16 EPA priority polycyclic aromatic hydrocarbons. Anal. Chim. Acta 2016, 915, 81-89. [CrossRef] 
32. Yamamoto, Y.; Ishizaki, A.; Kataoka, H. Biomonitoring method for the determination of polycyclic aromatic hydrocarbons in hair by online in-tube solid-phase microextraction coupled with high performance liquid chromatography and fluorescence detection. J. Chromatogr. B 2015, 1000, 187-191. [CrossRef]

33. Rivera-Figueroa, A.M.; Ramazan, K.A.; Finlayson-Pitts, B.J. Fluorescence, Absorption, and Excitation Spectra of Polycyclic Aromatic Hydrocarbons as a Tool for Quantitative Analysis. J. Chem. Educ. 2004, 81, 242. [CrossRef]

34. Bao, L.; Sheng, P.; Li, J.; Wu, S.; Cai, Q.; Yao, S. Surface enhanced Raman spectroscopic detection of polycyclic aromatic hydrocarbons (PAHs) using a gold nanoparticles-modified alginate gel network. Analyst 2012, 137, 4010. [CrossRef] [PubMed]

35. Wang, L.; Wang, X.M.; Gao, R.; Lu, D.F.; Qi, Z.M. Nanoporous Gold Films Prepared by a Combination of Sputtering and Dealloying for Trace Detection of Benzo[a]pyrene Based on Surface Plasmon Resonance Spectroscopy. Sensors 2017, 17, 1255. [CrossRef] [PubMed]

36. Haruna, K.; Saleh, T.A.; Hossain, M.K.; Al-Saadi, A.A. Hydroxylamine Reduced Silver colloid for Naphthalene and Phenanthrene detection using Surface-Enhanced Raman Spectroscopy. Chem. Eng. J. 2016, 304, 141-148. [CrossRef]

37. Guerrini, L.; Garcia-Ramos, J.V.; Domingo, C.; Sanchez-Cortes, S. Sensing Polycyclic Aromatic Hydrocarbons with Dithiocarbamate-Functionalized Ag Nanoparticles by Surface-Enhanced Raman Scattering. Anal. Chem. 2009, 81, 953-960. [CrossRef] [PubMed]

38. Hong, S.; Kang, T.; Oh, S.; Moon, J.; Choi, I.; Choi, K.; Yi, J. Label-free sensitive optical detection of polychlorinated biphenyl (PCB) in an aqueous solution based on surface plasmon resonance measurements. Sens. Actuators B Chem. 2008, 134, 300-306. [CrossRef]

39. Nguyen, A.L. Detection of polychlorinated biphenyls by photoactivated fluorescence and by sensitized laser photolysis. Anal. Chim. Acta 1996, 319, 221-229. [CrossRef]

40. Belfatmi, R.; Lamotte, M.; Ait-Lyazidi, S.; Violet, P.F. Detection of PCBs in natural waters by front face fluorometry on solid sorbent on account of their fluorescence quantum yields and interaction with humic substances. Chemosphere 2005, 61, 761-769. [CrossRef]

41. Hu, X.; Meng, G.; Huang, Q.; Zhu, C.; Chen, B.; Huang, Z.; Li, F.; Wang, Z. Nano-petri-dish Array Assisted Glancing Angle Sputtering for Ag-NP Assembled Bi-nanoring Arrays as Effective SERS Substrates. ACS Appl. Mater. Interfaces 2014, 6, 7991-7995. [CrossRef]

42. Shanta, P.V.; Cheng, Q. Graphene Oxide Nanoprisms for Sensitive Detection of Environmentally Important Aromatic Compounds with SERS. ACS Sens. 2017, 2, 817-827. [CrossRef]

43. Bantz, K.C.; Haynes, C.L. Surface-enhanced Raman scattering detection and discrimination of polychlorinated biphenyls. Vib. Spectrosc. 2009, 50, 29-35. [CrossRef]

44. Lu, Y.; Yao, G.; Sun, K.; Huang, Q. $\beta$-Cyclodextrin coated $\mathrm{SiO}_{2} @ \mathrm{Au} @ \mathrm{Ag}$ core-shell nanoparticles for SERS detection of PCBs. Phys. Chem. Chem. Phys. 2015, 17, 21149-21157. [CrossRef] [PubMed]

45. Chen, J.; Huang, Y.; Kannan, P.; Lin, Z.; Zhang, J.; Guo, L.; Chen, T. Flexible and Adhesive SERS Active Tape for Rapid Detection of Pesticide Residues in Fruits and Vegetables. Anal. Chem. 2016, 88, 2149-2155. [CrossRef] [PubMed]

46. Yao, G.H.; Liang, R.P.; Huang, C.F.; Wang, Y.; Qiu, J.D. Surface Plasmon Resonance Sensor Based on Magnetic Molecularly Imprinted Polymers Amplification for Pesticide Recognition. Anal. Chem. 2013, 85, 11944-11951. [CrossRef] [PubMed]

47. Zhang, K.; Mei, Q.; Guan, G.; Liu, B.; Wang, S.; Zhang, Z. Ligand Replacement-induced fluorescence switch of quantum dots for ultrasensitive detection of organophosphorothioate pesticides. Anal. Chem. 2010, 82, 9579-9586. [CrossRef] [PubMed]

48. Kubackova, J.; Fabriciova, G.; Miskovsky, P.; Jancura, D.; Sanchez-Cortes, S. Sensitive Surface-Enhanced Raman Spectroscopy (SERS) Detection of Organochlorine Pesticides by Alkyl Dithiol- Functionalized Metal Nanoparticles-Induced Plasmonic Hot Spots. Anal. Chem. 2014, 87, 663-669. [CrossRef] [PubMed]

49. Azab, H.A.; Khairy, G.M.; Kamel, R.M. Time-resolved fluorescence sensing of pesticides chlorpyrifos, crotoxyphos and endosulfan by the luminescent Eu(III)-8-allyl-3- carboxycoumarin probe. Spectrochim. Acta Part A Mol. Biomol. Spectrosc. 2015, 148, 114-124. [CrossRef]

50. Mauriz, E.; Calle, A.; Manclús, J.J.; Montoya, A.; Hilderbrandt, A.; BarcelÓ, D.; Lechuga, L.M. Optical immunosensor for fast and sensitive detection of DDT and related compounds in river water samples. Biosens. Bioelectron. 2007, 22, 1410-1418. [CrossRef] 
51. Chen, Y.; Ge, F.; Guang, S.; Cai, Z. Low-cost and large-scale flexible SERS-cotton fabric as a wipe substrate for surface trace analysis. Appl. Surface Sci. 2017, 436, 111-116. [CrossRef]

52. Fleischmann, M.; Hendra, P.J.; Mcquillan, A.J. Raman spectra of pyridine adsorbed at a silver electrode. Chem. Phys. Lett. 1974, 26, 163-166. [CrossRef]

53. Thi, B.H.N. Surface-Enhanced Raman Scattering (SERS) for In-Situ Analysis of Mixture of Polycyclic Aromatic Hydrocarbons (PAHs) in Sea-Water. Ph.D. Thesis, Technische Universität Berlin, Berlin, Germany, 2004.

54. Ding, G.; Xie, S.; Liu, Y.; Wang, L.; Xu, F. Graphene oxide-silver nanocomposite as SERS substrate for dye detection: Effects of silver loading amount and composite dosage. Appl. Surface Sci. 2015, 345, 310-318. [CrossRef]

55. Shi, G.; Wang, M.; Zhu, Y.; Shen, L.; Wang, Y.; Ma, W.; Chen, Y.; Li, R. A flexible and stable surface-enhanced Raman scattering (SERS) substrate based on Au nanoparticles/Graphene oxide/Cicada wing array. Opt. Commun. 2018, 412, 28-36. [CrossRef]

56. Szlag, V.M.; Sarahi, R.R.; Jiayi, H.E.; Hudson-Smith, N.V.; Hyunho, K.; Ngoc, L.; Reineke, T.M.; Haynes, C.L. Molecular Affinity Agents for Intrinsic Surface-enhanced Raman Scattering (SERS) Sensors. ACS Appl. Mater. Interfaces 2018, 10, 31825-31844. [CrossRef] [PubMed]

57. Huang, J.; Chen, F.; Zhang, Q.; Ma, D.; Xu, K.; Zhao, Y. 3D Silver Nanoparticles Decorated Zinc Oxide/Silicon Heterostructured Nanomace Arrays as High-Performance Surface-Enhanced Raman Scattering Substrates. ACS Appl. Mater. Interfaces 2015, 7, 5725-5735. [CrossRef]

58. Hu, F.; Lin, H.; Zhang, Z.; Liao, F.; Shao, M.; Lifshitz, Y.; Lee, S.T. Smart Liquid SERS Substrates based on $\mathrm{Fe}_{3} \mathrm{O}_{4} / \mathrm{Au}$ Nanoparticles with Reversibly Tunable Enhancement Factor for Practical Quantitative Detection. Sci. Rep. 2014, 4, 7204. [CrossRef]

59. Liang, H.; Li, Z.; Wang, W.; Wu, Y.; Xu, H. Highly Surface-roughened “Flower-like” Silver Nanoparticles for Extremely Sensitive Substrates of Surface-enhanced Raman Scattering. Adv. Mater. 2009, 21, 4614-4618. [CrossRef]

60. Sun, Y.; Liu, K.; Miao, J.; Wang, Z.; Tian, B.; Zhang, L.; Li, Q.; Fan, S.; Jiang, K. Highly Sensitive Surface-Enhanced Raman Scattering Substrate Made from Superaligned Carbon Nanotubes. Nano Lett. 2010, 10, 1747-1753. [CrossRef] [PubMed]

61. Zhang, Z.; Lu, D.F.; Liu, Q.; Qi, Z.; Yang, L.; Liu, J. Wavelength-interrogated surface plasmon resonance sensor with mesoporous-silica-film-enhanced sensitivity to small molecules. Analyst 2012, 137, 4822-4828. [PubMed]

62. Zhang, Z.; Liu, J.; Qi, Z.M.; Lu, D.F. In situ study of self-assembled nanocomposite films by spectral SPR sensor. Mater. Sci. Eng. C Mater. Biol. Appl. 2015, 51, 242-247. [CrossRef]

63. Rapiphun, J.; Sopis, C.; Saengrawee, S.; Akira, B.; Sukon, P. Functional Conducting Polymers in the Application of SPR Biosensors. J. Nanotechnol. 2012, 2012, 1-7.

64. Wood, W.R. On a Remarkable Case of Uneven Distribution of Light in a Diffraction Grating Spectrum. Proc. Phys. Soc. Lond. 1902, 18, 269-275. [CrossRef]

65. Otto, A. Excitation of nonradiative surface plasma waves in silver by the method of frustrated total reflection. Zeitschrift Für Physik a Hadrons Nuclei 1968, 216, 398-410. [CrossRef]

66. Kretschmann, E.; Raether, H. Notizen: Radiative Decay of Non Radiative Surface Plasmons Excited by Light. Zeitschrift Für Naturforschung A 1968, 23, 2135-2136. [CrossRef]

67. Nylander, C.; Liedberg, B.; Lind, T. Gas detection by means of surface plasmon resonance. Sens. Actuators 1983, 3, 79-88. [CrossRef]

68. Breault-Turcot, J.; Masson, J.F. Nanostructured substrates for portable and miniature SPR biosensors. Anal. Bioanal. Chem. 2012, 403, 1477-1484. [CrossRef] [PubMed]

69. Li, J.; Lu, D.F.; Zhang, Z.; Liu, Q.; Qi, Z.M. Hierarchical mesoporous silica film modified near infrared SPR sensor with high sensitivities to small and large molecules. Sens. Actuators B Chem. 2014, 203, 690-696. [CrossRef]

70. Ashley, J.; Piekarska, M.; Segers, C.; Trinh, L.; Rodgers, L.; Willey, R.; Tothill, E. An SPR based sensor for allergens detection. Biosens. Bioelectron. 2016, 88, 109-113. [CrossRef]

71. Zhang, P.; Chen, Y.P.; Wang, W.; Shen, Y.; Guo, J.S. Surface plasmon resonance for water pollutant detection and water process analysis. TrAC Trends Anal. Chem. 2016, 85, 153-165. [CrossRef] 
72. Miura, N.; Sasaki, M.; Sakai, G.; Gobi, K.V. Regenerable surface plasmon resonance (SPR)-based immunosensor for highly sensitive measurement of sub-ppb levels of benzo (a) pyrene. Chem. Lett. 2002, 31, 342-343. [CrossRef]

73. Yin, P.; Wang, Y.; Li, Y.; Deng, C.; Zhang, X.; Yang, P. Preparation of sandwich-structured graphene/mesoporous silica composites with C8-modified pore wall for highly efficient selective enrichment of endogenous peptides for mass spectrometry analysis. Proteomics 2012, 12, 2784. [CrossRef]

74. Tao, Y.; Kanoh, H.; Abrams, L.; Kaneko, K. Mesopore-Modified Zeolites: Preparation, Characterization, and Applications. Chem. Rev. 2006, 106, 896-910. [CrossRef] [PubMed]

75. Vyhmeister, E.; Valdés-González, H.; Muscat, A.J.; Sulleiman, D.; Estévez, L.A. Surface Modification of Porous Silicon-Based Films Using Dichlorosilanes Dissolved in Supercritical Carbon Dioxide. Ind. Eng. Chem. Res. 2013, 52, 4762-4771. [CrossRef]

76. Michael, S. Fluorescence-based Biosensors. In Encyclopedia of Analytical Chemistry; Meyers, R.A., Ed.; John Wiley \& Sons Ltd.: Hoboken, NY, USA, 2011.

77. Reid, C. Book Reviews: Excited States in Chemistry and Biology. Science 1957, 126, 1021.

78. Ariese, F.; Gooijer, C.; Velthorst, N.H. Application of fluorescence spectroscopic techniques in the determination of PAHs and PAH metabolites. Tech. Instrum. Anal. Chem. 2000, 21, 789-824.

79. Nsibande, S.A.; Forbes, P.B.C. Fluorescence detection of pesticides using quantum dot materials-A review. Anal. Chim. Acta 2016, 945, 9-22. [CrossRef] [PubMed]

80. Yang, R.; Dong, G.; Sun, X.; Yang, Y.; Yu, Y.; Liu, H.; Zhang, W. Feasibility of the simultaneous determination of polycyclic aromatic hydrocarbons based on two-dimensional fluorescence correlation spectroscopy. Spectrochim. Acta Part A Mol. Biomol. Spectrosc. 2018, 190, 342-346. [CrossRef] [PubMed]

81. Apicella, B.; Ciajolo, A.; Tregrossi, A. Fluorescence Spectroscopy of Complex Aromatic Mixtures. Anal. Chem. 2004, 76, 2138-2143. [CrossRef] [PubMed]

82. Chen, W.; Qi, F.; Li, C.; Cao, J.; Li, Z.; Dou, J.; Bei, Y.; Zhan, J.; Zhu, Q. Functionalized polysilsesquioxane film fluorescent sensors for sensitive detection of polychlorinated biphenyls. J. Organomet. Chem. 2014, 749, 296-301. [CrossRef]

83. Fernández-Sánchez, J.F.; Carretero, A.S.; Cruces-Blanco, C.; Fernández-Gutiérrz, A. The development of solid-surface fluorescence characterization of polycyclic aromatic hydrocarbons for potential screening tests in environmental samples. Talanta 2003, 60, 287-293. [CrossRef]

84. Fernández-Sánchez, J.F.; Carretero, A.S.; Cruces-Blanco, C.; Fernández-Gutiérrez, A. Highly sensitive and selective fluorescence optosensor to detect and quantify benzo[a]pyrene in water samples. Anal. Chim. Acta 2004, 506, 1-7. [CrossRef]

85. Adegoke, O.; Montaseri, H.; Nsibande, S.A.; Forbes, P.B.C. Alloyed quaternary/binary core/shell quantum dot-graphene oxide nanocomposite: Preparation, characterization and application as a fluorescence "switch ON" probe for environmental pollutants. J. Alloys Compd. 2017, 720, 70-78. [CrossRef]

86. Yang, L.; Chen, B.; Luo, S.; Li, J.; Liu, R.; Cai, Q. Sensitive detection of polycyclic aromatic hydrocarbons using $\mathrm{CdTe}$ quantum dot-modified $\mathrm{TiO}_{2}$ nanotube array through fluorescence resonance energy transfer. Environ. Sci. Technol. 2010, 44, 7884. [CrossRef] [PubMed]

(C) 2019 by the authors. Licensee MDPI, Basel, Switzerland. This article is an open access article distributed under the terms and conditions of the Creative Commons Attribution (CC BY) license (http://creativecommons.org/licenses/by/4.0/). 